\title{
Hjartastopp hjá unglingsstúlku - sjúkratilfelli
}

Valentínus P. Valdimarsson ${ }^{1}$ leknir, Girish Hirlekar ${ }^{5}$ æknir, Oddur Ólafsson ${ }^{5}$ æknir, Gylfi Óskarsson ${ }^{4}$ læknir, Hróðmar Helgason ${ }^{4}$ læknir, Sigurður E. Sigurðsson ${ }^{4}$ æknir, Hildur Tómasdóttir ${ }^{1}$ æknir, Kristján Eyjólfsson $\left.{ }^{3}\right|_{æ}$ knir, Tómas Guðbjartsson ${ }^{2,6} \mid æ k n i r$

\section{ÁGRIP}

Hjartastopp er sjaldgæft hjá börnum og unglingum. Lýst er 12 ára stúlku sem fór í hjartastopp eftir brátt hjartadrep par sem beita varð langvarandi hjartahnoði og hjarta- og lungnavél til að bjarga lífi hennar. Við kransæðapræðingu vaknaði grunur um flysjun í vinstri kransæðarstofni og var pví komið fyrir kransæðastoðneti. Samdráttur hjartans lagaðist og var hjartaog lungnavélin aftengd viku síðar. Hún útskrifaðist heim en hálfu ári síðar sást endurprenging í stoðnetinu og var pví gerð kransæðahjáveituaðgerð. Á tölvusneiðmyndum sást að um meðfæddan galla var að ræða par sem vinstri kransæðarstofn átti upptök frá hægri ósæðarbolla í stað pess vinstra. Tilfellið sýnir að kransæðamissmíð getur valdið lífshættulegu hjartadrepi.

\section{Tilfelli}

'Svæfinga- og Hraust 12 ára gömul stúlka var stödd á sundæfingu gjörgæsludeild, ${ }^{2}$ hjartaog lungnaskurðdeild, og lungnaskurddeild,
hjartadeild Landspítala, ${ }^{4}$ Barnaspítala

Hringsins, ${ }^{5}$ svæefingaog giörgæsludeild Sjúkrahússins á Akureyri, ${ }^{6}$ læknadeild Háskóla Íslands. pegar hún fann skyndilega fyrir mæði og kastaði upp. Hún var flutt á Sjúkrahúsið á Akureyri (SA) og átti pá erfitt með öndun en gat talað. Á bráðamóttöku mældist blóðprýstingur 90/45 mmHg, púls 70 slög á mínútu og súrefnismettun $100 \%$ með $10 \mathrm{~L} /$ mín af súrefni á maska. Á lungnamynd sáust dreifðar íferðir (mynd 1) og hjartalínurit sýndi tíð ofansleglaslög og hægri öxulbreytingar, en ekki ST-breytingar. Fyrsta mæling á CK-MB í sermi, sem gerð var 45 mínútum eftir að einkenni hófust, var eðlileg $(5,1 \mu \mathrm{g} / \mathrm{L}$, eðlilegt gildi $<7 \mu \mathrm{g} / \mathrm{L})$ og sömuleiðis Trópónín T (<0,01 ug/L, eðlilegt gildi <0,01 ug/L) (mynd 2).

Einni og hálfri klukkustund eftir komu á SA versnaði öndun stúlkunnar og hún var barkaprædd. Kom ljósrauður froðukenndur vökvi úr barkarennunnni. Í fyrstu vaknaði grunur um ásvelgingarlungnabólgu og voru henni gefin sýklalyf í æð, bólgueyðandi sterar og pvag-

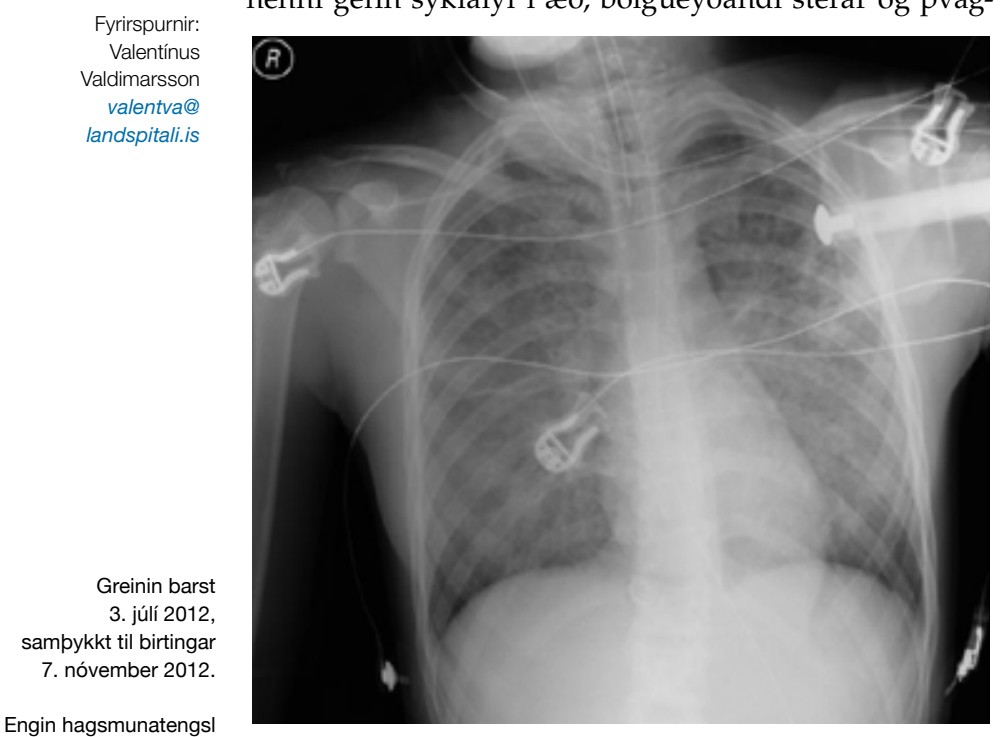

gefin upp. Mynd 1. Röntgenmynd af lungum við komu á Sjúkrahús Akureyrar. ræsilyf. Ákveðið var að fá tölvusneiðmyndir af lungum en á röntgendeildinni fór hún skyndilega í hjartastopp með sleglahraðtakti. Hafin var endurlífgun og henni gefin samdráttarhvetjandi lyf í æð (adrenalín, noradrenalín, levosimendan, phenylephrine, vasopressin). Náðist hún í sinustakt klukkutíma síðar og voru pá fengnar tölvusneiðmyndir (án skuggaefnis) sem sýndu dreifðar péttingar í lungum líkt og við brátt andnauðarheilkenni (acute respiratory distress syndrome, ARDS). Einnig var gerð ómskoðun á hjarta sem sýndi verulega skertan samdrátt vinstra slegils og mældist útfallsbrot (ejection fraction, EF) undir 10\% (eðlilegt 55-70\%). Vegna lágs blóðprýstings varð að beita hjartahnoði með stuttum hléum næstu prjár klukkustundirnar en síðan varð ástand hennar stöðugra.

Ákveðið var að senda stúlkuna með sjúkraflugi á Landspítala en á leiðinni purfti aftur að beita hjartahnoði tímabundið í nokkur skipti vegna hægatakts og lágs blóðprýstings. Við komu á Landspítala var hún færð rakleiðis á hjartaskurðstofu. Meðan á hjartahnoði stóð var hún tengd við ECMO-dælu (extracorporeal membraneous oxygenation) sem er afbrigði af hjarta- og lungnavél. Slöngum fyrir dæluna var komið fyrir í innri hóstarbláæð (internal jugular vein, 17 Fr) og hægri

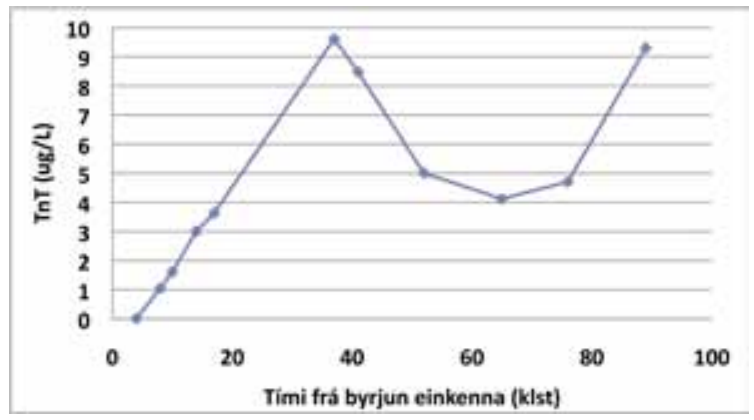

Mynd 2. Trópónín T mælingar í sermi (ug/L) (eðlilegt gildi $<0,01$ ug/L). 


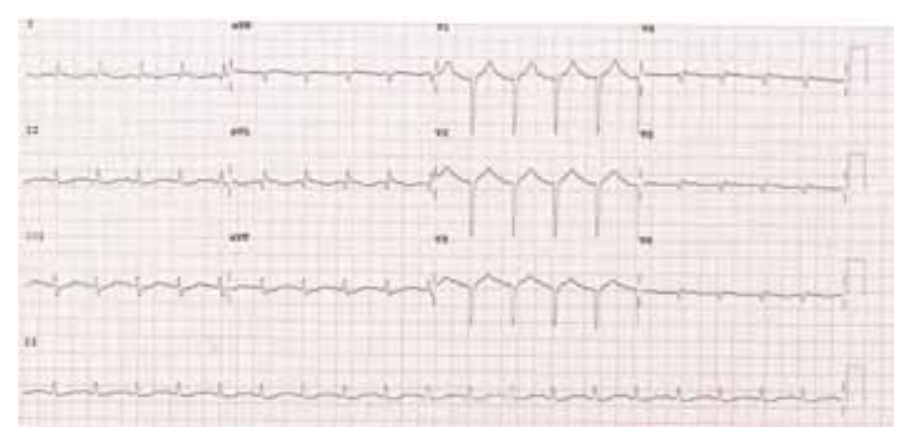

Mynd 3. Hjartalínurit sólarhring eftir að einkenni hófust. Greinilegar ST-hækkanir oo Q-takkar eru sjáanlegir íleiðslum V1-V3.

náraslagæð (external femoral artery, 14 Fr). Við petta hækkaði blóðprýstingur og súrefnismettun en ómskoðun á skurðstofu sýndi að útfallsbrot vinstri slegils mældist aðeins 10\% prátt fyrir fulla ECMO-meðferð.

Eftir ECMO-meðferð í hálfan sólarhring sáust greinileg merki bráðs hjartadreps á hjartalínuriti (mynd 3) með verulegri hækkun

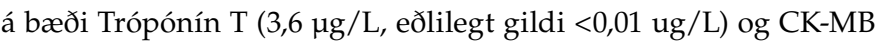
(437 $\mu \mathrm{g} / \mathrm{L}$, eðlilegt gildi $<7 \mu \mathrm{g} / \mathrm{L}$ ) (mynd 2). Pví var ákveðið að gera kransæðapræðingu sem sýndi $90 \%$ prengsli á $10 \mathrm{~mm}$ kafla í vinstri kransæðarstofni (mynd 4). Talið var líklegast að um flysjun (dissection) í æðinni væri að ræða og pví var ákveðið að koma fyrir kransæðastoðneti (Integrity ${ }^{\circledR}$ 2,75/12 mm). Einnig var hafin blóðpynnandi meðferð með intrifíban (Integrilin ${ }^{\circledR}$ ) og asetýlsalisýlsýru (Hjartamagnýl ${ }^{\circledast}$ ). Daginn eftir mældist útfallsbrot vinstri slegils 20\% á fullri ECMO-meðferð. Sama dag bar á stífleika í hægri kálfa sem reyndist rýmisheilkenni (compartment syndrome). Voru vöðvafell í kálfanum pví opnuð með fellisskurði (fasciotomy). Blóðrás út í hægri ganglim lagaðist við skurðinn en ekki nægjanlega. Pví var lítil (7 Fr) hliðarslanga tengd frá slagæðaslöngu ECMO-dælunnar út í grynnri hluta hægri lærisslagæðar (superficial femoral artery).

Par sem samdráttur hjartans var óbreyttur á fjórða degi veikinda (útfallsbrot 20\%) var ákveðið að senda stúlkuna til Gautaborgar ef meðferð með hjálparhjarta (ventricular assist device) eða hjartaígræðslu væri pörf. Við komu pangað var hægri fótur áberandi kaldur. Kom í ljós að segi hafði myndast í hliðarslöngu frá ECMOdælunni út í lærisslagæð og náðist að fjarlægja hann. ECMO-meðferð var haldið áfram næstu tvo sólarhringa en 6 dögum frá upphafi veikinda var hægt að aftengja dæluna. Mældist útfallsbrot vinstri slegils pá $40 \%$ og minni pörf fyrir samdráttarhvetjandi lyf. Tveimur dögum síðar varð að fjarlægja hluta af vöðvum í hægri kálfa vegna dreps. Ástand hennar lagaðist enn frekar og meðferð í öndunarvél var hætt á 12. degi veikinda. Tveimur vikum frá upphafi veikinda var hún flutt aftur á Landspítala. Ekki komu upp alvarlegar sýkingar eða nýrnabilun í sjúkrahúslegunni. Stúlkan var síðan útskrifuð á SA 42 dögum eftir að veikindi hófust og mældist útfallsbrot vinstri slegils pá $50 \%$.

Fjórum mánuðum síðar var stúlkan kölluð í eftirlit og kransæðapræðingu en hún var pá einkennalaus frá hjarta. Par sást marktæk prenging (60\%) í stoðneti í vinstri kransæðarstofni. Ákveðið var að gera kransæðahjáveituaðgerð par sem fremri vinstri brjóstholsslagæð (left internal mammary artery, LIMA) var tengd á vinstri framveggskvísl (left anterior descending artery, LAD). Aðgerðin gekk vel og útfallsbrot vinstri slegils eftir aðgerð mældist í kringum 40\%. Eftir aðgerðina var ákveðið að fá tölvusneiðmyndir af hjarta

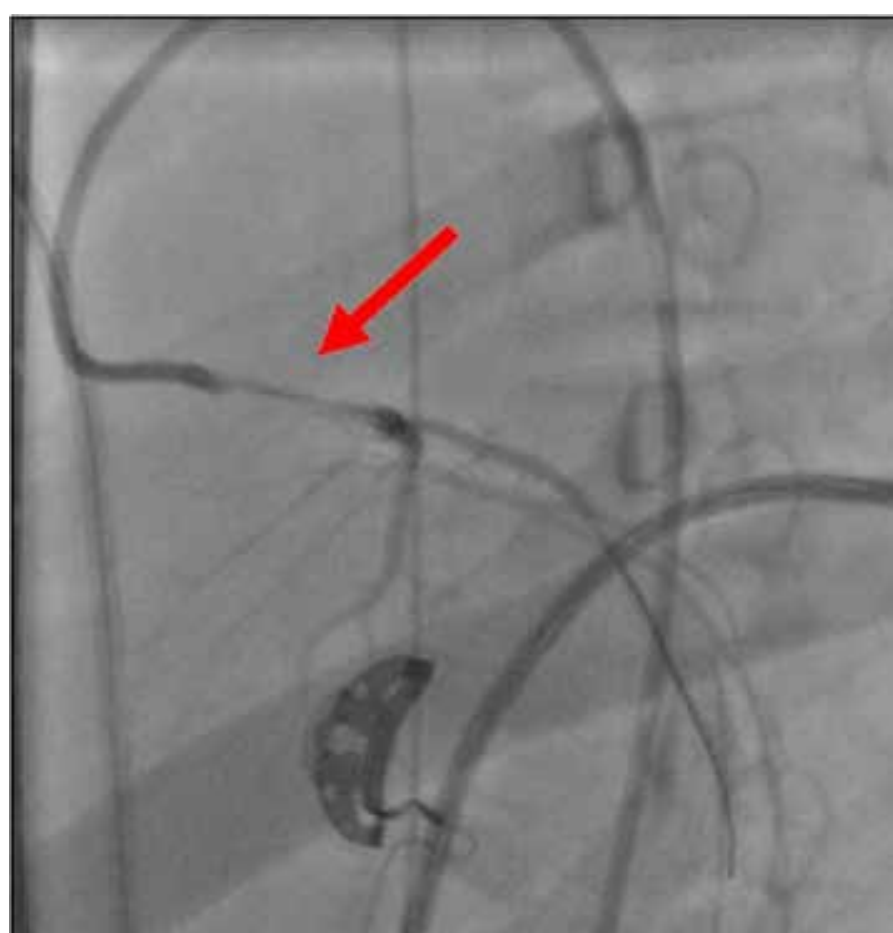

Mynd 4. Kransæðapræðing sólarhring eftir að einkenni hófust. Prengsli sjást vel á 10 mm kafla í vinstri kransæðarstofni (ör).

og kransæðum og kom pá í ljós missmíð á kransæðum. Eins og sést á mynd 5 átti vinstri kransæð upptök frá hægri ósæðarbolla (aortic sinus) í stað pess vinstra og lá vinstri kransæðarstofn á milli ósæðar og lungnaslagæðar. Ellefu dögum eftir aðgerð var stúlkan útskrifuð heim til sín við góða líðan. Tæpum tveimur árum síðar stundar hún bæði skóla og ípróttir en húðskyn á hægri fótlegg er skert og hreyfigeta í kálfavöðvum minnkuð. Brjóstverkir og einkenni hjartabilunar hafa hins vegar ekki gert vart við sig og útfallsbrot vinstra slegils nánast eðlilegt, eða í kringum 50\%.

\section{Umræða}

Petta tilfelli sýnir hvernig missmíð á vinstri kransæðastofni getur valdið truflun á blóðflæði til hjartavöðva og bráðu hjartadrepi. Pví er mikilvægt að hafa missmíðar á kransæðum í huga hjá börnum og unglingum með bráð einkenni um hjartadrep.

Missmíð á kransæðum og Kawasaki-sjúkdómur eru algengustu orsakir hjartadreps hjá börnum og unglingum og geta valdið hjartastoppi. ${ }^{1}$ Hjartastopp verður hins vegar oft af völdum meðfæddra hjartagalla, öndunarstopps, takttruflana, slyss og lyfjagjafar en í mörgum tilfellum finnst orsök ekki. ${ }^{2}$ Dánarhlutfall barna og unglinga sem fara í hjartastopp er hátt. Aðeins 10\% barna sem fara í hjartastopp utan sjúkrahúsa lifa en 25\% barna sem fara í hjartastopp innan sjúkrahúsa. ${ }^{3}$ Á undanförnum árum virðist lifun pó hafa batnað vegna bættrar gjörgæslumeðferðar en einnig vegna kælimeðferðar og notkunar á ECMO-dælu. ${ }^{3}$

Missmíðar á kransæðum er sjaldgæft fyrirbæri og greinast hjá 0,3-1,6\% einstaklinga. ${ }^{4}$ Pær eru vel pekkt ástæða fyrir skyndidauða ungs fólks, sérstaklega við áreynslu sem oft tengist ípróttaiðkun. Er talið að orsök hjartastopps hjá ípróttafólki megi í 17\% tilfella rekja til missmíða á kransæðum. ${ }^{5}$ Missmíðum á kransæðum er oft skipt í prennt. Upptök kransæðar geta verið afbrigðileg eða meðfædd prengsl og jafnvel lokun verið til staðar. Loks getur kransæð 


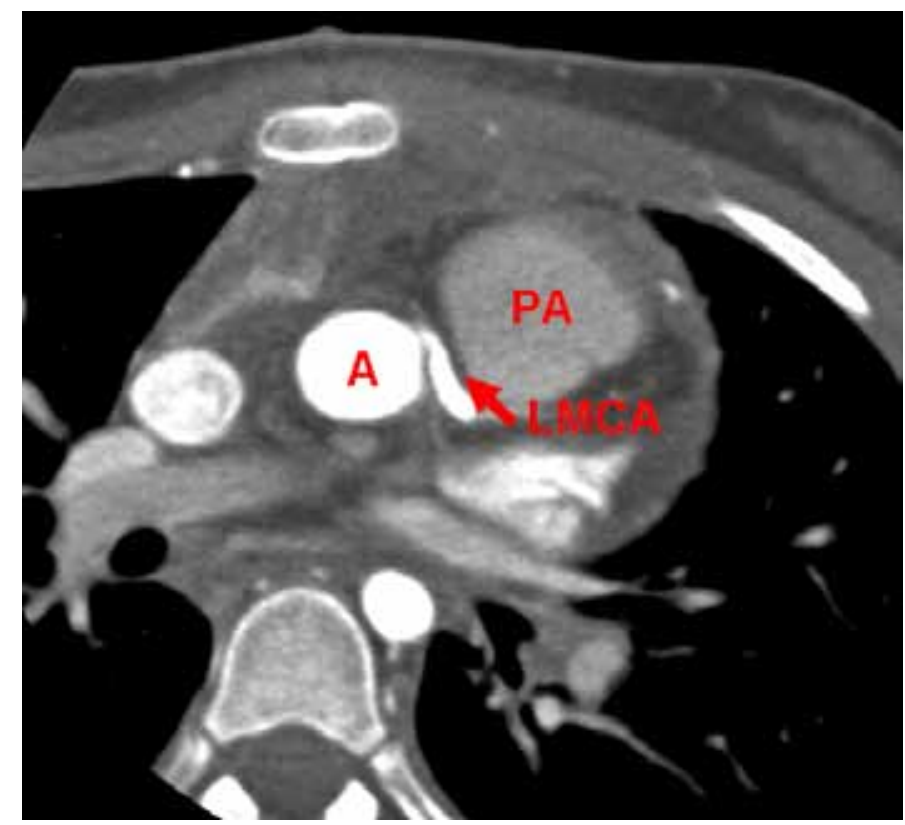

Mynd 5. Tölvusneiðmynd af hjarta sem sýnir upptök vinstri kransæðar (LMCA) frá hægri ósæðarbolla í stað pess vinstra. Vel sést hvernig kransæðin liggur á milli ósæðar (A) og lungnaslagæðar (PA).

vantað alveg. Sumar pessara missmíða eru lífshættulegar og tilfelli greinast stundum fyrst við krufningu. Oftar er pó greiningin gerð vegna einkenna sem gera vart við sig stuttu eftir fæðingu eða á barnsaldri. Í öðrum tilfellum er greiningin ekki gerð fyrr en á fullorðinsaldri og sumir fullorðnir greinast fyrir tilviljun (án einkenna). ${ }^{1,4,6}$

Í pessu tilfelli voru upptök vinstri kransæðarstofns frá hægri ósæðarbolla í stað pess vinstra. Á mynd 5 sést hvernig vinstri kransæðarstofn liggur á milli ósæðar og lungnaslagæðar. Um er að ræða vel pekkta orsök fyrir hjartadrepi og skyndidauða hjá unglingum og yngri fullorðnum. ${ }^{1,6}$ Ýmis afbrigði af pessari missmíð eru til en hættulegast er afbrigðið eins og pað sem sást í pessu tilfelli. ${ }^{4}$ Nokkrir samverkandi pættir eru taldir geta skert blóðflæði til hjartans. ${ }^{7}$ Kransæðaopið prengist par sem hornið á milli vinstri kransæðastofns og ósæðar er óeðlilega knappt. Einnig er talið að prýstingur verði á kransæðastofninn par sem hann liggur á milli ósæðar og lungnaslagæðar, sérstaklega við áreynslu pegar útfall hjartans er aukið og æðarnar víðari. Loks er talið að endurtekin blóðpurrðarköst geti valdið örmyndun í hjarta og skemmt leiðslukerfið sem getur valdið lífshættulegum takttruflunum og yfirliði við áreynslu. ${ }^{6-8}$ Brjóstverkir eru pó algengara einkenni hjá pessum sjúklingum og hjartadrep getur tengst áreynslu eins og við ípróttaiðkun. ${ }^{6,7}$

Petta tilfelli undirstrikar hversu erfitt getur verið að greina hjartadrep hjá börnum og unglingum. Við komu á SA sáust dreifðar íferðir á lungnamynd og lék grunur á ásvelgingarlungnabólgu. Tæpum sólarhring síðar voru greinileg merki um kransæðaprengsli, meðal annars ST-hækkanir og Q-takkar á hjartalínuriti. Einnig voru hjartaensím hækkuð og samdráttur vinstri slegils skertur á hjartaómun. Kransæðapræðing sýndi síðan 90\% preng- ingu í kransæðarstofni sem helst var talin skýrast af flysjun í æðinni. Flysjun er pekkt í kransæðum en er sjaldgæf orsök fyrir bráđu hjartadrepi og skyndidauða hjá börnum og unglingum, en aðeins tveimur tilfellum hefur verið lýst. ${ }^{9}{ }^{10}$ Hugsanlegt er að flysjun hafi orðið í kransæðinni vegna langvarandi hjartahnoðs enda pótt erfitt sé að færa sönnur á pað. Með stoðneti tókst að bæta flæði í æðinni en síðar gerði endurprenging vart við sig en pað er vel pekktur fylgikvilli stoðneta hjá fullorðnum. ${ }^{11}$ Reynsla af notkun stoðneta hjá börnum er mjög takmörkuð enda vaxa pau ekki með barninu og parf pví oftast að gera kransæðahjáveitu síðar.

Greining á kransæðamissmíð lá fyrst fyrir pegar tölvusneiðmynd af hjarta var gerð, hálfu ári frá upphafi veikinda. Við endurskoðun kransæðamynda sást óeðlileg afstaða kransæðaopa sem getur verið vísbending um missmíð. Hafa verður í huga að kransæðamyndatakan var gerð við afar erfiðar aðstæður með sjúklinginn tengdan við ECMO-dælu. Og pótt greining á missmíð hefði legið fyrir frá upphafi var meðferð með ECMO-dælu óumflýjanleg. Pegar endurprenging greindist í stoðnetinu var kransæðahjáveita besta úrræðið en stoðnet í kransæðastofni gerði erfiðara um vik að gera svokallaða „unroofing“ aðgerð par sem upptök kransæðarinnar eru færð til., ${ }^{72}$

Ljóst er að ECMO-dæla bjargaði lífi stúlkunnar en við komu á Landspítala var hún með svæsna hjarta- og lungnabilun. Pannig var blóðflæði til vefja tryggt og hjartað hvílt eftir stórt hjartadrep og langvarandi hjartahnoð. Auk pess var með gervilunga ECMO-dælunnar hægt að halda súrefnismettun í slagæðablóði yfir $90 \%$. Fyrstu dagana hélst útfall vinstri slegils undir 10\% en eftir vikumeðferð í ECMO-dælu hafði pað aukist í 40\% og pví hægt að aftengja dæluna. Skýringuna á pessum bætta samdrætti hjartans er afturkræf blóðpurrð í hjartavöðvanum sem getur varað í nokkra daga. Petta fyrirbæri kallast „,stunning“ og er vel pekkt eftir kransæðaprengsli hjá fullorðnum. ${ }^{13}$

Blóðpurrð til ganglima er vel pekktur fylgikvilli ECMO-meðferðar og má rekja til truflaðs blóðflæðis vegna dæluslangna. Petta á sérstaklega við hjá börnum og unglingum sem hafa fíngerðari æðar en fullorðnir.14, 15 Í pessu tilfelli var notast við $10 \mathrm{Fr}$ slagæðaslöngu, en með henni náðist 2,5 L flæði á mínútu sem nægði til að hvíla bæði hjarta og lungu. Pegar greining rýmisheilkennis lá fyrir var strax gerður fellisskurður en síðan komið fyrir aukaslöngu (7 Fr) handan stóru dæluslöngunnar til að auka blóðflæði út í gangliminn. Pessar ráðstafanir dugðu pó ekki til, par sem drep varð í hægri kálfavöðvum og hefur blóðsegi í hliðarslöngunni eflaust haft sitt að segja.

Hjartastoppp hjá börnum og unglingum á sér margar orsakir en er sem betur fer sjaldgæft fyrirbæri. Í pessum tilfellum er mikilvægt að hafa missmíðar á kransæðum í huga svo greining tefjist ekki. Í pessu tilfelli skipti árangursríkt hjartahnoð og ECMO-meðferð sköpum.

Pakkir fá læknarnir Bjarni Torfason og Pórarinn Guðnason á Landspítala og Mats Synnergren á Drottning Silvias barn- och ungdomssjukhus í Gautaborg. Skriflegt leyfi liggur fyrir frá aðstandendum sjúklings fyrir birtingu pessa tilfellis í Læknablađinu. 


\section{Heimildir}

1. Reich JD, Campbell R. Myocardial infarction in children. Am J Emerg Med 1998; 16: 296-303.

2. Engdahl J, Axelsson A, Bång A, Karlson BW, Herlitz J. The epidemiology of cardiac arrest in children and young adults. Resuscitation 2003; 58: 131-8.

3. Topjian AA, Nadkarni VM, Berg RA. Cardiopulmonary resuscitation in children. Curr Opin Crit Care 2009; 15 203-8.

4. Hauser M. Congenital anomalies of the coronary arteries. Heart 2005; 91: 1240-5.

5. Maron BJ, Doerer JJ, Haas TS, Tierney DM, Mueller FO Sudden deaths in young competitive athletes: analysis of 1866 deaths in the United States, 1980-2006. Circulation 2009: 119: 1085-92.

6. Basso C, Maron BJ, Corrado D, Thiene G. Clinical profile of congenital coronary artery anomalies with origin from the wrong aortic sinus leading to sudden death in young competitive athletes. J Am Coll Cardiol 2000; 35: 1493-501.
7. Basso C. Congenital Coronary Artery Anomalies at Risk of Myocardial Ischaemia and Sudden Death. European Cardiology. 2005;1(1):1-5.

8. Kannam HC, Satou G, Gandelman G, DeLuca AJ, Belkin $\mathrm{R}$, Monsen $\mathrm{C}$, et al. Anomalous origin of the left main coronary artery from the right sinus of Valsalva with an intramural course identified by transesophageal echocardiography in a 14 year old with acute myocardial infarction. Cardiol Rev 2005; 13: 219-22.

9. Kothari D, Ruygrok P, Gentles T, Occleshaw C. Spontaneous coronary artery dissection in an adolescent man with systemic lupus erythematosus. Int Med J 2007; 37: $342-3$

10. Rohit MK, Garg PK, Hariram V, Gupta A, Grover A Idiopathic spontaneous coronary artery dissection presenting as acute myocardial infarction in a young boy. Ind Heart J 2008; 60: 346-8.
11. Fischman DL, Leon MB, Baim DS, Schatz RA, Savage MP, Penn I, et al. A randomized comparison of coronarystent placement and balloon angioplasty in the treatment of coronary artery disease. Stent Restenosis Study Investigators. N Engl J Med 1994; 331: 496-501.

12. Romp RL, Herlong JR, Landolfo CK, Sanders SP, Miller $\mathrm{CE}$, Ungerleider RM, et al. Outcome of unroofing procedure for repair of anomalous aortic origin of left or right coronary artery. Ann Thor Surg 2003; 76: 589-95.

13. Gross GJ, Kersten JR, Warltier DC. Mechanisms of postischemic contractile dysfunction. Ann Thor Surg 1999; 68: 1898-1904.

14. Foley PJ, Morris RJ, Woo EY, Acker MA, Wang GJ, Fairman $\mathrm{RM}$, et al. Limb ischemia during femoral cannulation for cardiopulmonary support. J Vasc Surg 2010; 52: 850-3.

15. Gander JW, Fisher JC, Reichstein AR, Gross ER, Aspelund $\mathrm{G}$, Middlesworth $\mathrm{W}$, et al. Limb ischemia after common femoral artery cannulation for venoarterial extracorporeal membrane oxygenation: an unresolved problem. J Pediatr Surg 2010; 45: 2136-40.

\section{ENGLISH SUMMARY}

\section{Cardiac arrest in a teenager - a case report}

Valdimarsson VTh'1, Hirlekar $\mathrm{G}^{5}$, Olafsson $\mathrm{O}^{5}$, Oskarsson $\mathrm{G}^{2}$, Helgason $\mathrm{H}^{2}$, Sigurdsson $\mathrm{SE}^{5}$, Tomasdottir $\mathrm{H}^{1}$, Eyjolfsson $\mathrm{K}^{3}$, Gudbjartsson $\mathrm{T}^{4,6}$

Cardiac arrest is rarely seen in children and teenagers. We present a 12-year old girl with cardiac arrest following myocardial infarction, that required prolonged cardiac massage and extracorporeal-membranousoxygenation (ECMO). At coronary angiography the left main coronary artery (LMCA) was stented for a suspected coronary dissection. The contraction of the heart improved and the ECMO-treatment was discont- inued a week later. The patient was discharged home, but six months later a coronary artery bypass surgery was performed for in-stent restenosis. Further work-up with computed tomography (CT) showed that the LMCA originated from the right aortic sinus instead of the the left one. This case demonstrates how life threatening myocardial infarction can be caused by coronary artery anomalies.

Key words Coronary anomaly, pediatric, myocardial infarction, acute coronary syndrome, acute heart failure, extracorporeal membraneous oxygenation (ECMO).

Correspondence: Valentínus Valdimarsson valentva@landspitali.is

${ }^{1}$ Departments of Anesthesia and Intensive Care, ${ }^{2}$ Pediatrics, ${ }^{3} \mathrm{Cardiology}$ and ${ }^{4} \mathrm{Cardiothoracic} \mathrm{surgery,} \mathrm{Landspitali} \mathrm{University} \mathrm{Hospital,}{ }^{5}$ Department of Anesthesia and Intensive Care, Akureyri Hospital, ${ }^{6}$ Faculty of Medicine, University of Iceland.

Styttur Sérlyfjaskrártexti: Avamys (flútíkasónfúróat) nánari upplýsingar er að finna á vef Lyfjastofnunar, www.serlyfjaskra.is ${ }^{1}$.

Avamys nefúði, dreifa, hver úðaskammtur inniheldur 27,5 míkrógrömm af flútíkasónfúróati. Ábendingar: Avamys er ætlað til meðferðar við einkennum ofnæmiskvefs. Skammtar og lyfjagjöf: Avamys-nefúði er eingöngu til notkunar í nef. Til að ná hámarksárangri af meðferðinni er mælt með reglulegri notkun. Fullorðnir og unglingar (12 ára og eldri): Ráðlagður upphafsskammtur er tveir úðaskammtar í hvora nös einu sinni á dag. begar fullnægjandi stjórn á einkennum hefur náðst gæti minni skammtur, einn úðaskammtur í hvora nös nægt til viðhaldsmeðferðar. Skammturinn skal stilltur á minnsta skammtinn sem viðheldur fullnægjandi stjórn á einkennum. Börn (6 til 11 ára): Ráðlagður upphafsskammtur er einn úðaskammtur hvora nös einu sinni á dag. Sjúklingar sem sýna ekki fullnægjandi svörun við einum úðaskammti í hvora nös einu sinni á dag geta notað tvo úðaskammta í hvora nös einu sinni á dag. Pegar fullnægjandi stjórn á einkennum hefur náðst er mælt með pví að minnka skammtinn niður í einn úðaskammt í hvora nös, einu sinni á dag. Börn yngri en 6 ára: Takmörkuð reynsla er af notkun lyfsins hjá börnum yngri en 6 ára. Öryggi og verkun hjá pessum hópi hafa ekki verið vel staðfest. Aldraðir sjúklingar og sjúklingar með skerta nýrnastarfsemi: Engin pörf er á aðlögun skammta hjá pessum hópum. Sjúklingar með skerta lifrarstarfsemi: Engin pörf er á aðlögun skammta pegar um væga eða miðlungsmikla skerðingu á lifrarstarfsemi er að ræða. Engar upplýsingar liggja fyrir um sjúklinga með mikið skerta lifrarstarfsemi. Frábendingar: Ofnæmi fyrir virka efninu eða einhverju hjálparefnanna. Sérstök varnaðarorð og varúðarreglur við notkun: Flútíkasónfúróat umbrotnar verulega í fyrstu umferð um lifur, pví er líklegt að almenn útsetning fyrir flútíkasónfúróati, gefnu um nef, sé aukin hjá sjúklingum með alvarlegan lifrarsjúkdóm. Áhrif á líkamann í heild geta komið fram vegna notkunar barkstera í nef. Hugsanleg altæk áhrif geta verið Cushing-heilkenni, einkenni sem líkjast Cushing-heilkenni, bæling á nýrnahettum, vaxtarskerðing hjá börnum og unglingum, drer í auga, gláka og enn sjaldnar ýmis sálræn áhrif og áhrif á hegðun p.m.t. skynhreyfiofvirkni, svefntruflanir, kvíði, punglyndi eða árásarhneigð. Greint hefur verið frá hægari vexti hjá börnum, sem fengu 110 míkrógrömm af flútíkasónfúróati daglega í eitt ár. bví skulu börn fá lægsta virka skammt sem veitir viðunandi stjórn á sjúkdómseinkennum. Meðferð með stærri skömmtum en ráðlagðir eru af barksterum í nef, getur leitt til klínískt marktækrar bælingar á nýrnahettum. Ef einhver ástæða er til að ætla að starfsemi nýrnahettna sé skert verður að gæta varúðar pegar sjúklingar eru teknir af barksterum með almenna verkun og settir á flútíkasónfúróat. Avamys inniheldur bensalkóníumklóríð. Milliverkanir við önnur lyf og aðrar milliverkanir: Brotthvarf flútíkasónfúróats gerist hratt með verulegum umbrotum í fyrstu umferð um lifur, fyrir tilstilli cýtókróm P450 3A4. Samhliða gjöf rítónavírs ekki ráðlögð vegna hættunnar á aukinni almennri útsetningu fyrir flútíkasónfúróati. Gæta skal varúðar pegar flútíkasónfúróat er gefið samhliða öflugum CYP3A4-hemlum par sem ekki er hægt að útiloka aukna péttni í líkamanum í heild. Frjósemi, meðganga og brjóstagjöf: Engar fullnægjandi niðurstöður liggja fyrir varðandi notkun flútíkasónfúróats hjá punguðum konum. Flútíkasónfúróat skal aðeins nota á meðgöngu ef ávinningur fyrir móðurina er meiri en möguleg áhætta fyrir fóstrið eða barnið. Ekki er vitað hvort flútíkasónfúróat skilst út í brjóstamjólk hjá konum. Hjá konum með barn á brjósti ætti gjöf flútíkasónfúróats einungis að koma til greina ef væntanlegt gagn fyrir móðurina er meira en hugsanleg áhætta fyrir barnið. Aukaverkanir: Mjög algengar: blóðnasir. Algengar: höfuðverkur, saramyndur í nefi. Sjaldgæefar: verkur í nefi, óbægindi í nefi (b.m.t. sviði, erting og særindi í nefi), burrkur í nefi. Mjög sjaldgaefar: ofnæmisviðbrögð, m.a. bráðaofnæmi, ofsabjúgur, útbrot og ofsakláði. Tỉðni ekki pekkt: vaxtarskerðing. Ofskömmtun: Ólíklegt er að bráð ofskömmtun parfnist annarrar meðferðar en eftirlits. Afgreiðslutilhögun: lyfseðilsskylt, R, E, ATC flokkur: R01AD12. Pakkningar og verð: Úðatæki, 120 skammtar, hámarkssmásöluverð 1. september 2012, kr 2.820 Markaðsleyfishafi: Glaxo Group Ltd, Greenford, Middlesex, UB6 0NN, Bretland.

Dagsetning endurskoðunar textans: $20-07-2012$, IS/FF/0001b/12

Tilkynning um aukaverkanir: Aukaverkanir má tilkynna á vef Lyfjastofnunar:

www.lyfjastofnun.is/Aukaverkanir/tilkynna eða til GlaxoSmithKline í síma 5303700. 